Paideusis

\title{
Ethics and the Special Education Assistant
}

\section{Lise Birkeland}

Volume 17, Number 1, 2008

URI: https://id.erudit.org/iderudit/1072468ar

DOI: https://doi.org/10.7202/1072468ar

See table of contents

Publisher(s)

Canadian Philosophy of Education Society

\section{ISSN}

0838-4517 (print)

1916-0348 (digital)

Explore this journal

Cite this article

Birkeland, L. (2008). Ethics and the Special Education Assistant. Paideusis, 17(1), 59-65. https://doi.org/10.7202/1072468ar

\section{Article abstract}

The need for and responsibilities of Special Education Assistants (also known as Teacher Assistants, Teacher Aides, and Education Assistants) in British Columbia are increasing; yet time to consult, plan and receive direction is decreasing due to teachers' burgeoning workloads and time constraints. Coupled with the fact that SEA's often have more specific knowledge of the student's label and educational interventions, these dynamics sometimes create a climate of misunderstanding and confusion of the roles and responsibilities of teachers and their assistants. At times, SEA's feel unsupported and forced to take on responsibility without authority as they navigate through the ethics of what is the best inclusive practice for the student with special needs. By using an ethical approach to analyze an example of a) the Special Education Assistant's working life and b) one extreme experience of that life, insight into the varied nature of this world is illuminated.
This document is protected by copyright law. Use of the services of Érudit (including reproduction) is subject to its terms and conditions, which can be viewed online.

https://apropos.erudit.org/en/users/policy-on-use/ 
Paideusis, Volume 17 (2008), No. 1, pp. 59-65

\title{
Ethics and the Special Education Assistant
}

\author{
LISE BIRKELAND \\ Simon Fraser University, Canada
}

\begin{abstract}
The need for and responsibilities of Special Education Assistants (also known as Teacher Assistants, Teacher Aides, and Education Assistants) in British Columbia are increasing; yet time to consult, plan and receive direction is decreasing due to teachers' burgeoning workloads and time constraints. Coupled with the fact that SEA's often have more specific knowledge of the student's label and educational interventions, these dynamics sometimes create a climate of misunderstanding and confusion of the roles and responsibilities of teachers and their assistants. At times, SEA's feel unsupported and forced to take on responsibility without authority as they navigate through the ethics of what is the best inclusive practice for the student with special needs. By using an ethical approach to analyze an example of a) the Special Education Assistant's working life and b) one extreme experience of that life, insight into the varied nature of this world is illuminated.
\end{abstract}

Long ago, an old Native American Elder told her grandson a story. "There are two wolves fighting inside all of us constantly - the wolf of fear and hate, and the wolf of love and peace". The grandson listened, then looked up at his grandfather and asked, "Which one will win?" The grandfather replied "The one we feed." (Author unknown)

Life is constantly presenting us with a choice of which mouth to feed. Choosing a life of love and peace is akin to choosing to live a good life or, according to Aristotle (2000) a life of happiness, of aiming at the good. Many people act from an internal sense of right and wrong, assuming that the morals they were raised with will suffice in generally doing the right thing. But how many people actually ponder their acts from the aspect of virtuous behavior? Moreover, how closely do people dissect their actions and decisions in terms of their effect on those around them? In other words, what form of 'good' should we try to attain? Aristotle suggests that we should deliberate on our actions, on our moral virtues, in order to actively try to achieve the good through the sense of excellences. Thus in all actions, to select the correct behaviors, or the good, is in a sense selecting the wolf of love and peace within.

One group in particular who could be said to very actively deal with the rights and wrongs of ethical practices in the day to day life of the school, whether they are conscious of it or not, are teachers-particularly those who educate children at the elementary level. Within this field of teachers lies a sometimes unnoticed group of educators who work hard to integrate students with special needs into the mainstream school system- the Special Education Assistants.

For the past ten years, I have experienced many joys and frustrations helping with the integration of autistic students in the mainstream classroom. I come from the perspective that their presence is a vital part of the school environment. Neuro-typical students who witness their peer's struggle learn so much from their differently-abled classmates, including empathy, compassion, patience, open mindedness and the ability to accept and appreciate difference (Lucyshyn 2006). They

(C) Copyright 2008. The author, Lise Birkeland, assigns to Paideusis the right of first publication and educational and non-profit institutions a non-exclusive license to use this document for personal use and in courses of instruction provided that the article is used in full and this copyright statement is reproduced. Any other usage is probibited without the express permission of the author. 
learn there is no one way to do something, that everybody belongs and can succeed.

Questions can be raised asking whose right is it to decide what someone else should know. Who chooses? Whose choice are we programming? When we train a student to act a certain way, how is that different than brainwashing? My answer to that lies in the team approach. Ricoeur (1992) suggests we respect standards of excellence within the practice and the best way to do that is to consult with others, as Campbell (2003) suggests-parents, caregivers, classroom and resource teachers, special education assistants, school and home specialist workers all working together to decide how best to support the student, all with the best interests of the student in mind. This then translates into careful investigating and planning through functional analysis, and using the baseline information to set up the intervention that will shape the desired behavior. Done properly, the results can be outstanding.

Unfortunately, this aforementioned group of SEA's often falls through the cracks of recognition within the system because at times they are not considered real educators. If they are considered at all, they are known as the "para-professionals"- the "aides" or "assistants" who work with "those" students with special needs, even though, according to the Ministry of Education Manual of Policies, Procedures, and Guidelines for Special Education Services, "Inherent in the School Act and Special Education Policy, Procedures and Guidelines is the teacher's responsibility for designing, implementing and evaluating the educational program, and the teacher assistant's role is to assist teachers in this responsibility. Both the teacher and the teacher assistant facilitate the inclusion of students with special needs. It is their joint role to encourage the student to become an independent learner and member of the classroom, school, and community"(p. 8).

My focus in this paper is on the ethical frame of this group of Special Education Assistants who support students with autism within the mainstream classrooms with the additional question of whether they truly belong within the CUPE union. Which wolf do we really feed?

\section{The Aim of SEAing}

If one were to ask any SEA why they do what they do, they would answer to make a difference in the lives of children, or as Noddings (2003) would agree, because they have an ethic of care. Clearly, the internal goods of wishing to help others, as well as some external goods such as a dependable paycheck and convenient hours for those wishing to be available for their kids when they come home from school, outweigh the disadvantages of the position. But by how much? Hard work, stress, little recognition or support, few hours, mediocre pay and little preparation or consultation time put SEAing in a category less suitable for the faint of heart, and more for those determined to see through the obstacles to the personal satisfaction gained from a job well done.

Whether or not teachers agree with the trend towards inclusion, more and more children with special needs, autism in particular, are entering the system every year. Parents of these children have become stronger advocates for their children, more knowledgeable of their rights, and more vocal in their demands that schools honor their needs.

With these children comes specialized staff to support their needs within the school system, in the form of Special Education Assistants. They come with a specific knowledge and skill set, targeted to enhance the school experience of the child with the disability. Often they possess knowledge and skills that are unique to the situation but which seem foreign to the teachers "in charge" such as the classroom teacher or resource teacher. Teachers sometimes worry whether they are prepared for both the inclusion of special needs students within their classroom as well as their SEA's.

How do teachers handle such situations? In my role as Special Education Assistant in elementary classrooms over the past 10 years I have witnessed many positive situations involving collaboration and communication between teachers and SEAs despite the lack of time and resources. According to the BC Ministry of Education (2006), "The practice of inclusion is not necessarily synonymous with full integration in regular classrooms, and goes beyond placement to include meaningful participation and 
the promotion of interaction with others". The ability to promote meaningful participation is possible when there is cooperation and trust between all parties.

The classroom is a microcosm of life that happens outside the four walls. When there is a symbiotic relationship between students and teacher, and trust is earned, it is possible to affect growth and change on a very meaningful level (Vanier 1998). Once an autistic student is introduced to such an environment, these dynamics are illuminated. The interactions and learning that occur during the school day mirror issues in the reality outside the four walls.

There is an opportunity then for students to examine issues of difference including the perspectives of acceptance, empathy and growth that can result. There is a need for active reciprocity among different people before community can arise, and acts of helping others seem to "interrupt the automatic processes of the banal, uneventful, or sensation-seeking ordinariness of young people" (Greene 1995, p. 10).

\section{The Realities of SEAing}

Having observed teachers in their classrooms for many years, I am awed by their capacity to make snap ethical decisions in the moment and respond to a multitude of students and a variety of needs at any given time. Like teachers, SEA's must make thousands of snap ethical decisions in the moment regarding what is the best aim for the student. Perhaps these decisions do not entail dealing with a full class of students, yet neither do they entail reacting solely to the student with special needs including autism, for most encounters involve other students to some degree as well, either on the playground or in the classroom.

The SEA must constantly assess the situation in the moment and from many different perspectives to decide what the morally correct action should be. Many considerations must be taken into account with ethical decisions revolving around social and academic aspects as well as around the teacher and the other students. SEA's are constantly weighing issues such as: the right of the student to be included versus the right of the other students to work uninterrupted by autistic behaviors, how much assistance to give versus promoting independence, how much to force a friendship by setting the stage to facilitate a union versus letting a bond form naturally, as well as at what point should we pull a student out of the classroom to avoid disturbing the other students versus honoring the student's coping style by keeping him in the classroom and addressing any problems there.

Some people ask why a student with autism seems to get out of having to do the same things as other students. I feel that this issue is one of equity versus equality. "British Columbia promotes an inclusive education system in which students with special needs are fully participating members of a community of learners. Inclusion describes the principle that all students are entitled to equitable access to learning, achievement and the pursuit of excellence in all aspects of their educational programs" (Ministry of Education 2006). Equity implies impartial and just treatment, and the student with special needs deserves to be supported from a standpoint of where and as he or she is. By way of example, should a student suffer a heart attack, I would not refuse him CPR on the basis that since other students are not receiving the same treatment it is unfair!

Another issue has to do with the idea of social structure and how it gets reproduced within the school setting. There is a lot to be said for how school society acts as a mirror to one's life and actions. For example, through my own actions, what is my student with special needs learning about his contribution to the social structure of an ethical society? In the same vein, what are his/her more typical peers learning about societal aspects of inclusion and acceptance, of differences and of openness and tolerance and problem solving? 


\section{When It Doesn't Work}

For the reality of inclusion to work, the autistic student first must move through the more systematic techniques of training in order to reach a level of independence and self-actualization. Such techniques are embedded within specific curriculum creation and implementation. For this curriculum to be effective, certain assessment practices must be put in place, such as the standards of goals and objectives and the accountability of Individual Education Plans. In theory, accountability ultimately lies with higher-level school personnel like the classroom and Resource teacher, who are typically less involved with the day to day management of the autistic student.

This imbalance of involvement sometimes leads to a top-heavy debate with Resource and classroom teachers on one side of the aisle and SEA's on the other. There is a feeling by the SEA that the person with the most knowledge on how to best support the inclusion of the autistic student has the least power. Her or his hands are tied because of her or his "para' professional position, lack of time to prepare, and mandated position of being under the guidance of the classroom teacher.

Additionally, the classroom teacher, who is often untrained in dealing with the needs of the autistic student, expects the SEA to magically "fix" situations that around the student with special needs. At the same time, the SEA depends on the Resource teacher, who is often similarly unknowledgeable, for support and guidance. Meanwhile, the Resource teacher, overwhelmed by the demand for her time and attention by more typical students, is unable to devote the attention necessary to the classroom teacher, let alone the SEA. Thus, while pondering the general question of when does the reality catch up to our ideal version of inclusion, we can also ask: Who is really running the show?

\section{An Example}

The following is a story that illustrates a situation where a class of students learned about an aspect of society that sometimes rears its ugly head. The teacher of a grade 3 class which included a boy with autism said she did not want him in her classroom. Her words were, "Take him out, work anywhere away from the classroom, do whatever you can with him." I was very surprised that this seemed to be the extent of our planning meeting. These words were not spoken during a time of collaboration; rather they were uttered over her shoulder as she walked down the hallway. As the SEA assigned to this student, and new to that particular school, I was expected to work with the student "under the direction of the teacher." However I felt torn between the dilemmas of the student's right to inclusion within his assigned classroom versus the wishes of his teacher who would not consider my knowledge or suggestions.

Now, granted, she was a newer teacher who was feeling significant fear of the unknown. She was surprised with the news that she was going to be assigned a student with autism and was both uncomfortable with the idea of having another adult in her classroom in the form of an SEA and dismissive of the positive contributions that an SEA could make. She was unprepared for a student with significant sensory and motor delays and challenging behaviors, and did not know what support she would be receiving.

Having been in many situations previously with teachers who were unsure of how to integrate such a student into their classrooms, my usual experience was one where the teacher and Resource teacher (who was usually the student's case manager) were able to meet and collaborate. I would share my skills and knowledge and suggest some ways to successfully integrate the student with autism. From there the teachers would agree to an initial program plan that I was to carry out, under the direction of the teacher.

Upon seeking the assistance of the resource teacher who was the case manager of the student, I was met with a similar indifference and unwillingness to address the situation. I was told that in this 
case, the teacher was the case manager of the student and that I should simply deal with her. This message was echoed upon consultation with the principal as well.

As I was the only SEA at this school, I was only able to discuss this situation with some colleagues at other schools. As a result of the situation, I felt forced to become very independent and to create my own program for this student that consisted of a means of communication, a daily schedule, appropriate academic learning materials, and alternate forms of creating social opportunities with other students. As my hours were the same as the hours the student was in the school, I did not have prep. time outside of being with the student. Therefore I used some of the student's learning time preparing materials for his program, as well as some of my own time. I also promoted his inclusion in other ways by highlighting his strengths and abilities, "visiting" other classrooms with sympathetic teachers, and doing lots of friendship facilitation work in the playground during lunch and recess.

Eventually the student and I were allowed back into his mainstream classroom after the student's successful program began to be noticed by everyone at the school and the teacher felt pressure to become involved with his program. His peers within the classroom were comfortable with his presence, having had the opportunity to both witness his growing social competence and to interact with him in various capacities. The societal message they received from this experience was that people with differences have to prove they are acceptable to be included.

\section{What Went Wrong?}

Had I not worked so hard to build bridges outside of the classroom with these peers as well as the rest of the school, the message the students could have taken with them into society, and perpetuated throughout their adult lives, might be that people who are perceived as different are not welcome. Looking back on this experience, I reflect on the huge responsibility I had, without the recognized authority to act. If what the student becomes in society is a test of the curriculum, then I want a program that I am involved in to reflect an inclusive attitude in both kids with special needs and their peers.

According to the joint BCTF/CUPE document: Roles and Responsibilities of Teachers and Teacher Assistants (2001, sec. 3.2), the Ministry of Education and the school district are both responsible for ensuring the necessary conditions for students with special needs to succeed on schools. One condition, "availability of a suitable workspace to accommodate the learning activities of those working with students with special needs," was clearly not met when the autistic student and I were essentially kicked out of the classroom and I was forced to seek out my own space to work with the student.

I was unable to initially provide "adequate resources to maintain an appropriate learning environment" (3.1) until I took the initiative to create materials by creatively using teaching time. Finally, "access to appropriate information regarding the student, the IEP, as well as techniques and strategies necessary to carry out the respective responsibilities of each in relation to student's programs" (3.3) was non-existent until I created the program for the student. Also at that time, there was not a strict adherence in creating and following an IEP, therefore there was no document or plan in place with which to use as a guideline.

\section{What is the Solution?}

How can we assure that SEA's are not faced with situations in which they have such huge responsibility without appropriate authority? How does this fit with the aim of the good life for students with special needs, and indeed their SEA's? Aritstotle (2000) advises that we trust people will do the right thing, and utilize best practice. Looking at this, I feel that SEA's would be able to produce their best practice in a designation outside of their current para-professional status within CUPE, where they are lumped into 
a group of essential, but non-educating workers such as caretakers, secretaries and maintenance workers.

They would be more effective in supporting students with special needs within the mainstream classroom and have a more streamlined rapport with teachers while being looked upon as professionals within a different regulative body. In order to be more cohesive and professionally recognized there would need to be a specific code of conduct and a professional association. Educational training in theoretical knowledge would have to be standardized throughout all training facilities, and this training would have to be evaluated through a recognized examination process. Perhaps then, with a new and more appropriate label, this group could then become a faction of the BCTF and enjoy the privileges that come with that, such as prep time, consultation time, autonomy, influence and respect.

\section{Conclusion}

The aim of the Special Education Assistant is fundamentally to be of service, with the internal goods of acting with care and wanting to help children outweighing the external goods. The working life of an SEA is filled with making snap ethical decisions in the moment, particularly regarding the best action to take with a child labeled autistic. Child centered dilemmas including the right of the student to be included versus the disruption of peers, as well as professional dilemmas such as working independently rather than following a contentious direction of the classroom teacher are examples of issues which contribute to an SEA's feeling of having great responsibility without authority. The story of what happens when a classroom teacher excludes a student and their SEA from the classroom serves as an example of how conditions of inclusion as laid out by the Ministry of Education-Special Education are sometimes not followed, leaving one to wonder if SEA's would be able to better serve their students from within a union other than CUPE, so that the wolf of love and peace can be fed.

\section{References}

Aristotle. (2000). Nicomachean ethics R. Crisp, (Ed.). Cambridge: Cambridge University Press.

Campbell, E. (2003). The ethical teacher. Maidenhead, U.K.: Open University Press.

Greene, M. (1995). Releasing the imagination: Essays on education, the arts and social change. San Francisco: Jossey-Bass Publishers.

Lucyshyn, J. M. (2006). Contextual Fit. In Encyclopedia of behavior modification and cognitive behavior therapy.. SAGE Publications. http://sage-reference.com/cbt/Article_3039.html/ (accessed March 1, 2007).

MacIntyre, A. (1984). The nature of virtues. In After virtue: A study in moral theory (2nd ed.). Notre Dame, IN: University of Notre Dame Press.

MacIntyre, A. (2006). Social Structures and their threats to moral agency. In Ethics and politics: Selected essays, vol.2. New York: Cambridge University Press.

Noddings, N. 2003. Is teaching a practice? Journal of Philosophy of Education, 37(2), 241-251.

Ricoeur, P. 1992. The self and the ethical aim. In Oneself as another. Chicago: University of Chicago Press.

Roles and responsibilities of teachers and teacher assistants: A BCTF/CUPE joint Paper. (2001). Vancouver BC: BC Teachers' Federation.

Special education services- $A$ manual of policies, procedures and guidelines for special education services. (2006). Victoria, BC: BC Ministry of Education, Special Education Services.

Vanier, J. (1998). Becoming human. Toronto: Anansi Press. CBC Massey Lectures series. 


\section{About the Author}

Lise Birkeland is pursuing her Masters of Education (Curriculum and Instruction focus) at Simon Fraser University. She has worked as a Special Education Assistant in the British Columbia public school system for the past ten years. Her particular interest is in the working lives of Special Education Assistants. She can be reached at newliseonlearning@telus.net 